doi: $10.19090 / \mathrm{i} .2021 .32 .116-132$

UDC: 94(497.11)"17" 904(497.11)"17"

\author{
ALEKSANDAR RISTIĆ \\ Dr. Milovan Spasić National Library, Rekovac \\ arh.aleksandar.ristic@gmail.com
}

\title{
THE VAMPIRLIJA HILL IN THE VILLAGE OF MIJAJLOVAC (TRSTENIK): A POSSIBLE LOCATION FOR THE BIRTHPLACE OF EUROPEAN 'VAMPIROLOGY'
}

\begin{abstract}
Vampires gained worldwide popularity due to the classic novel about the most famous one, Dracula, written by Bram Stoker in 1897. Bram Stoker's Dracula has very little in common with his inspiration, the fifteenth-century Wallachian ruler Vlad III (1431-1476), who was a real historical figure. However, some strange events involving the dead seem to have occurred in Southwest of Transylvania a few centuries after the Wallachian prince's death. In some parts of the Habsburg Kingdom of Serbia (1718-1739), the local Austrian authorities recorded some cases of 'vampirism', which Europe would be introduced to shortly afterward, along with this newly accepted word. This paper will present historical facts about one particular case recorded at the southernmost border of the Habsburg Empire, which at the time was the West Morava River. It was the case of a 'vampire' named Arnold Paole, who died in 1726/7 in the border village of Medveđa and whose case 'infected' the whole Europe with the 'virus' of 'vampiromania'. The main goal of the paper is to locate the spot where one of the first 'vampire slayings' ever recorded could have taken place, and to direct further investigations within early modern age archaeology.

Keywords: Arnold Paole, Medveđa, Levač, District of Jagodina, Kingdom of Serbia (17181739), Habsburg empire, necropolis, $18^{\text {th }}$ century archaeology.
\end{abstract}

$\mathrm{U}$ nlike Bram Stoker's Dracula, the most famous literary and movie vampire who never existed, some real 'vampires' caused disorder among the population of eighteenth-century Serbia, frightening the Austrian authorities of the time. This is confirmed by historical documents that would later draw a great deal of attention throughout the Old Continent. The intention and purpose of this paper is not to overburden the reader with detailed and varied ethnographical, anthropological, and literary data about the phenomenon of vampires and vampirism. There are plenty of academic works regarding this topic. The introduction will instead look back at the archaeological aspect of this issue, for which there is already documented data about specific ritual practices that reflect certain human beliefs. Consequently, we can conclude that the 'archeo-vampirology' already has a 
solid base in academic research. ${ }^{1}$

\section{Archaeological Evidence}

There are some necropolises in Serbia where certain burial customs have been recorded that appear to demonstrate people's 'fear of vampires'. For example, in a Roman necropolis in Ravna near Knjaževac, the grave of a woman was found containing an iron knife in the area of the chest and a needle between the legs, which had probably been attached to the deceased's garment. One explanation could be that the knife and needle, which were placed symmetrically along an imaginary axis, were to protect not only the deceased but also to protect the living from the woman's spirit. ${ }^{2}$ Some graves at Više Grobalja, one of Viminacium's eastern necropolises, also had nails which were not connected in any way to the wooden coffins. In a few cases, the deceased's legs had been nailed to the bottom of the wooden coffin or to the bottom of the grave pit, so the living could safely return to their homes and remain there peacefully without fear of the deceased becoming 'vampirized'. This necropolis contains a large number of unusual graves, which can be associated with the population's beliefs about the 'dead rising' after death. ${ }^{3}$

At the medieval necropolis in Trnjane, a few cases of dismembered skeletons have been noted as a manifestation of the local population's fear of the 'living dead'. The bones separated from the rest of the skeleton usually include the spine, ribcage, vertebrae, arms, and legs. A equal number of cases like this were found in graves of both females and males. ${ }^{4}$ Similar cases have been documented in medieval necropolises in Korbovo, Prahovo, Niš, and Radljevo with what appeared to be charred wood around the bones of the limbs, chest, and skull, presumably as a product of attempts to ward off evil spirits. The basis for this can be found in ethnographic material. ${ }^{5}$ Also, these finds in the archaeological record have been confirmed in some medieval written sources. One of these is the twentieth clause of Dušan's Code from the fourteenth century, which prohibits exhuming the dead and burning corpses. ${ }^{6}$ Similar cases have documented in Croatia ${ }^{7}$ and in other surrounding areas. ${ }^{8}$ All of these archaeological sites date from different historical periods and geographical areas, but further archaeological data could demonstrate similar human beliefs in a vast chronological and territorial range. ${ }^{9}$

\footnotetext{
A significant paper was written by D. Barrowclough, who collected many accounts of 'vampire' funerals throughout the Balkans and Europe. However, this author also warns that assuming each unconventional 'deviant' grave is a 'vampire' grave, might be dangerous in archeological conclusions. See: Barrowclough 2014a: 1-10. For more by the same author, see: Id. 2012: 1-21; Id. 2014b: 1-12; Barrowclough, Hallam 2008: 93-102. See also: Krumphanzlová 1961: 544-549; Id. 1966: 277-327; Grenz 1967: 255-265; Warnke 1982: 113-117; Hanuliak 1999: 577-585; Leszek, Kajkowski 2013: 780-796; Betsinger, Scott 2014: 467-476; Koperkiewicz 2015: 491-505.

Petković, Ružić 2005: 140.

Korać, Golubović 2009: 528-529.

Marjanović-Vujović 1984: 68-69.

Marjanović-Vujović 1986: 68; Mirković-Marić 2013: 254.

Novaković 1898, 23.

Gusar 2012: 51; Azinović Bebek, Janeš 2016: 133; Krznar, Bedić 2016: 205.

Szabó 1964: 125--128; András 1984: 226; Rangochev, Hadžhiangelov 2012: 163-172.

The possibility of the continuity of a certain postmortem burial custom over time will not be considered.
} 
It is notable that of these archaeological finds do not have precise historical confirmation. We do not know why these people were suspected of being 'vampires'. Appearances of 'vampires' have been recorded in modern times as well, for which there detailed sources, mostly because they are so recent. The case presented in this paper is one of them. Unlike the previous examples, it is not known exactly where the event took place, and the main goal of this paper is to attempt to locate this place.

\section{Historical Background}

During the Great Turkish War (1683-1699), Austrian Habsburg troops seized control over the vast territories of present-day Serbia (1688-1690), but shortly afterward were forced to retreat. The Turkish state regained control over these areas, which was confirmed by the Treaty of Karlowitz in 1699. During the Austro-Turkish War (1716-1718), many Serbs joined the Habsburg army. Austria incorporated northern parts of present-day Central Serbia into the empire after the Treaty of Požarevac in 1718, and this new part of the empire became the Kingdom of Serbia. The southern border with the Ottoman Empire became the West Morava River. This remained unchanged until the next Austro-Turkish War (17371739), when the Habsburgs lost territories south of the Sava and Danube Rivers. ${ }^{10}$ These circumstances led to new Serbian migrations. ${ }^{11}$

As a new province of the Habsburg Empire, the Kingdom of Serbia was divided into districts. ${ }^{12}$ The settlements were divided into military (haiduk) villages, farming villages, trenches with People's militia and towns (Belgrade, Šabac, Kragujevac, etc.). ${ }^{13}$ After the Treaty of Požarevac in 1718, Austrians had maps drawn of the new territories and conducted a census of the population. The maps were drawn up by Ing. Captain Friedrich Öbshelwitz, and the census was led by Colonel Neipperg. The southernmost part of the Kingdom of Serbia along the left side of the West Morava River was part of the the Jagodina District (Jagodiner District), which included 17 inhabited settlements with 78 households and 19 abandoned settlements. ${ }^{14}$ One of the four commanders in Serbia at the time resided in Jagodina, where the Austrian troops were stationed. ${ }^{15}$ The border village of Medveđa (Midwedia), which is dealt with in this paper, was mentioned in both the census and the map (Fig.1). At that time, it was a village of six households. ${ }^{16}$ According to a list of the Serbian People's militia in 1725, Medveđa was under the control of Captain Andreas Hostinsky, who was stationed in Stalać. This village had one čardak on the banks of the West Morava

Certain cases, however, have led researchers to conclude that some archaeological data derived from graves could be the physical manifestation of the human fear of the dead.

10 Veselinović 1986: 106-111.

11 Veselinović 1986: 159-161; Mikavica et al. 2016: 212-213. For more on the migrations of the Serbs see: Popović 1954.

12 Langer 1889: 192; Popović 1950: 22; Veselinović 1986: 113, $n .19$.

13 Veselinović 1986: 116.

14 Langer 1889: 192; Popović 1950: 22; Veselinović 1986: 113, $n .19$.

15 Veselinović 114-115.

16 Popović 1950: 23. 
River. ${ }^{17}$ A few years later, in 1728/29 Medveđa and the nearby village of Ivanja were under the control of Captain of Vitanovac. ${ }^{18}$ The Jagodina District was under the jurisdiction of the Eparchy of Valjevo. In 1735, the village of Medveda was registered in this diocese as having 15 households. ${ }^{19}$ In 1737 Medveđa was one of the haiduk villages (hayduckendörfer) on the Austro-Turkish border, ${ }^{20}$ under the supervision of Captain Kesa (Ješa Milošević?) of the Campaign of Stalać. ${ }^{21}$

It was under these circumstances early in the eighteenth century that some strange events took place that entire empire would soon hear about. A report written on November 1731 by Schnepper, the commander in Jagodina, mentions '...in dem Heiduckhen Dorff Metewit grasirend[e] Kranckheit...[...a disease spreading in the haiduk village of Medveđa...]'. Because of this, the Ottoman commander was handed over to the Turks across the border, and the three more janissaries were held in the contumaz (i.e. quarantine). ${ }^{22}$ Fearing plague, Lieutenant colonel Schnapper (sometimes Schnezzer), sent a doctor stationed nearby named Glaser to Medveđa to investigate. ${ }^{23}$ Dr. Glaser's medical report, dated on December 12, 1731 was the first evidence of this case. He sent the report to the commander of Jagodina, which led to further investigation under the direction of the regimental officer Johhan Flückinger. A copy of the report was sent to the Collegium Sanitas in Vienna and to Glaser's father, a physicist from the Austrian capital.

Certain people from the village of Medveđa on the Morava complained about strange deaths occurring there, which led to a careful, house-to-house search on December 12, 1731. The medical team didn't find any trace of disease, except for some signs on the people's bodies, which the Austrians considered to be consequences of the Räzischen Fasten [Serbian religious fasting]. However, the villagers insisted that 13 inhabitants with symptoms like fever had died in Medveđa over the past six weeks. They believed the deaths had been caused by Vambyres [Vampires] or Bluthseiger [Bloodsuckers], and they would have to leave the village if the authorities did nothing about executing these 'vampires'.

The villagers claimed that it had all started with a 50-year-old woman named Milica, who had come to Medveđa six years ago from the Turkish side and had died seven weeks ago. Glaser arranged for ten graves to be exhumed so autopsies of the corpses could be conducted. Some of the bodies had decomposed, but some of them were bloated and bleeding and had traces of fresh blood in their mouths and noses. Doctor Glaser himself used the word 'vampire' when describing the undecomposed bodies. ${ }^{24}$ His father, Johannes Friedrich Glaser, wrote a note to Götz and Treu, editors of the Nuremberg journal Commercium Litterarium ad Rei Medicae et Scientiae, and his letter was published on February 13, 1732. He said that his son, Dr. Glaser, who lived in Paraćin, had written him a letter dated January 18, informing him that in this region, and especially in the village of

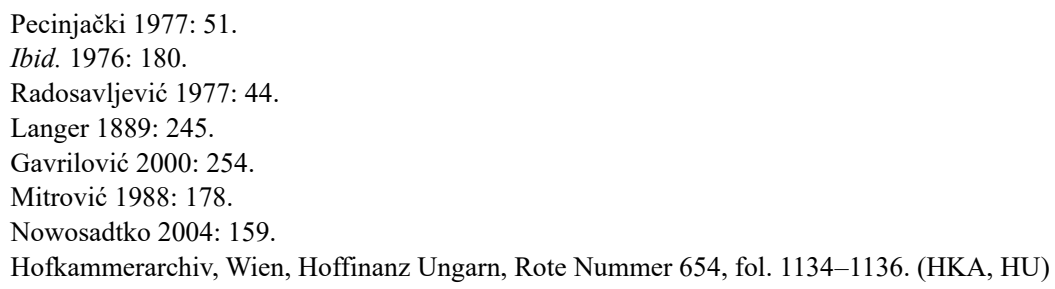


Medveđa near Paraćin '...magicam aliquam ab aliquo tempore grassari luem [a magical plague has been spreading for some time]'. Dr Glaser told him the dead had risen from their graves and killed the others, and that there had been a large number of deaths in a short period of time, which had forced the local authorities to order an investigation to resolve the issue. J. F. Glaser informed the Vienna audience of corpses being exhumed almost intact and then burned, and the ashes of these 'vampires' throw in the Morava River. ${ }^{25}$

Schnapper, the commander of Jagodina, sent Glaser's report to the Marquis Botta d'Adorno in Belgrade, who sent another commission to Medveđa. ${ }^{26}$ A detailed report entitled Visum et Repertum [Seen and Discovered] was compiled on January 26, 1732 in Belgrade, after a second investigation in Medveđa led by regimental field surgeon Johannes Flückinger and his team. ${ }^{27}$ They began by interviewing the local haiduk hadnack [militia captain], Goršić. According to him, the main problem was a local haiduk [militiaman] named Arnold Paole, who had come to Medveđa from the Ottoman Empire after eating dirt from a vampire's grave and smearing himself with the vampire's blood to protect himself from vampires. Five years previously (1726/7), he had broken his neck in an accident and died, and since then some people claimed they had been haunted by Arnold Paole, who, by the time Flückinger's team arrived, was considered responsible for the deaths of four people. At the suggestion of the local hadnack, the locals exhumed Arnold Paole's body forty days after his death. They found his body undecomposed with fresh blood leaking from his eyes, nose, mouth, and ears, and his clothes completely soaked in blood. After concluding that he was a 'vampire', they drove a stake through his heart. As they were hammering it in, they heard a groan coming from his mouth. They burned his body and threw the ashes into the grave. After that, they dug up the graves of four of Arnold Paole's 'victims'. Over a period of three months, seventeen healthy people suddenly died in Medveđa.

After the story of this haiduk, suspicious graves were exhumed, and the corpses were then given detailed medical and anthropological examinations by a surgeon named $\mathrm{J}$. Flückinger. During the examination of the thirteen bodies, the team found eleven that were in a 'vampiric' state, and some of them were bleeding abnormally. When the investigation was completed, the bodies were decapitated, the heads burned along with the corpses, and the ashes thrown in the Morava. According to signatures on a Flückinger's report, the event was witnessed by L.S. Johannes Flückinger, Regiment Field Surgeon of the Honorable B. Fürstenbusch Foot Regiment; L.S. J. H. Siegel, Field Surgeon of the Honorable Morall Regiment; and L.S. Johann Friedrich Baumgarten, Field Surgeon of the Honorable B. Fürstenbusch Foot Regiment. Under their signatures was written that this had been attested to by two additional signatories, L.S. Buttener, Lieutenant Colonel of the Honorable Alexandrian Regiment and L.S. J. H. von Lindenfels, Non-Commissioned Officer of the Honorable Alexandrian Regiment, and that everything related to 'vampires' '... in

\footnotetext{
Glaseri 1732: 82-83.

Mezes 2013: 33.

This report states that the village of Medveđa was '...an der türckischen Gräniz [...on the Turkish border],' which at the time was the West Morava River. Glaser's report more explicitly states that the village was located '...an der Morawa [on the Morava].' So, certain potential locations in the village of Medveda near presentday Despotovac, which was deep in the inner territory, cannot be accepted. See: Đorđević 2013: 159, n. 320; Đorđević, Miltojević 2014: 1617, n. 3.
} 
Augenschein genohmen, in allem und jedem der Wahrheit gemäß, und in unser selbsteigener Gegenwarth vorgenohmen, visitiret und examiniret worden [is in every way truthful and has been undertaken, observed, and examined in our presence]'. ${ }^{28}$

A message about supposed vampires in Medveđa was sent to the Marquis Botta, colonel and interim of Belgrade, about the medical and surgical investigation of January 7 , 1732. ${ }^{29}$ Another note, dated February 11, 1732 and sent to Marquis Botta said that 'approb[atur], was er weg[en] Vampirs anhero berichtet [what he has reported about vampires is confirmed],' and contained a request for a monetary reward from the Chamber for the field doctors who had been sent to Medveđa. It is interesting to note that there is no mention of these events in the Serbian ecclesiastical records from 1732 or later, which include various details about organization, churches, believers, the behavior of priests, customs etc. ${ }^{30}$ But, the acts of the Serbian People's Council held in May 1730 in Belgrade, contains what is presumably the first surviving use of the word vampire in the Serbian language. The sixteenth clause of the document dated May 30 forbids the investigation of vampires, with the threat of the anathema for those who disobey. ${ }^{31}$

It should be noted that this is not the first case of this phenomenon. An event in the village of Kisiljevo (Kisolova) in 1725 is usually considered the first appearance of 'vampirism' within the Habsburg Kingdom of Serbia. This is the well-known case of the 'first Serbian vampire', named Petar Blagojević (Peter Plogojoviz). ${ }^{32}$ However, a newspaper article from 1791 mentions a case of a vampire in Kragujevac that occurred in the same year as the one in Kisiljevo, but a few months earlier. ${ }^{33}$ Another case of a vampire was noted in the village of Kukljin, nearby Medveđa and just a few kilometers further down the West Morava River. Evidence of this case is found in a letter written by F. Kottwiz in Belgrade on January 26, $1732 .{ }^{34}$ After these cases, more reports appeared in other areas, including one of a vampire in the village of Žrnovo on the island of Korčula in $1748^{35}$ and another from Banat in 1753. ${ }^{36}$

Without getting into the details of various medical explanations given by experts in the field, there are still a few diseases that could have emerged in Serbia in the early

\footnotetext{
HKA, HU, RN 654, f. 1138-1140.

Mitrović 1988: 182.

See: Grujić 1914: 84-196.

'Заради вампировь предлагаті се надлежіт, да к тому такова^ не делают се. Сіе пребеззаконое дьло анаӨемою да запретит се, а преслушніци цесарскому суду да предадут се.'. See: Rajković 1872: 307.

2. Frombald 1725: 11-12.

33 Anon. 1791: 326-329. In this rather extensive description of the events from Kragujevac, the date of the medical examination of the vampire graves is given as April 6,1725. Also mention is that two vampires had passed away 72 and 56 days before, from which it can be concluded that one of them died and was buried in the second half of January, and the other during February of the same year. A report by Provisor Frombald about the case from Kisiljevo was published on July 21, 1725, mentions that Petar Blagojević has been dead '...bereits vor 10. wochen [...for 10 weeks already]', which places his death in approximately the first half of May of the same year. If a statement in a newspaper article from 1791 that claims the report was '...von dem Originalauffatze abgedruckt [reprinted from the original version]', it can be indirectly concluded that the first mention of the word vampire (Wampyren) originates from the report of the Kragujevac.

34 Anon. 1732a: 17; Ranfts 1734: 193.

35 Čoralić, Dugac, Sardelić 2014: 61-76.

36 Mézes 2019: 93-136.
} 
eighteenth century that were completely unknown to the local population. In 1732, in a dissertation defended in Leipzig, some philosophical and religious explanations were given to explain the phenomena reported in Medveđa, such as the postmortem decay of the body; postmortem growth of beards, hair and nails; the appearance of fresh blood in the deceased; etc. ${ }^{37}$ One historical document shows that the Austrian authorities in Belgrade forbade Patriarch Arsenije IV Jovanović from receiving more refugees from Serbia in 1739, because there was a fear that the infection (plague) could be spread to Racka Varoš (Serbian Belgrade). ${ }^{38}$ Some experts consider vampirism to be a consequence of tuberculosis or porphyria, but is more likely related to pellagra, which is caused by a lack of niacin (vitamin B3) or tryptophan. ${ }^{39}$ A hypothesis by Dr. J. Gomez is that the rabies virus was the cause of vampirismin the early eighteenth century, ${ }^{40}$ which was suspected in $1733 .{ }^{41}$ Some experts suggest that it was a result of the bacteria that causes anthrax. This bacterium can survive in the ground for decades in the form of spores, from which it can be transmitted to animals such as sheep through grazing. Humans can become infected by consuming mutton. And people eating together at different gatherings can lead to a larger outbreak and subsequent deaths in a short period of time. A typical symptom of anthrax is delirium. ${ }^{42}$

\section{The Vampirlija Hill in the Village of Mijajlovac: A possible location for these events?}

To locate the possible location where these interesting events took place, the presentday village of Medveđa is a good place to start. This village is located in Central Serbia on the left bank of the West Morava River along the road connecting Kraljevo and Trstenik with Kruševac, Jagodina, and Kragujevac via Rekovac. Administratively, it belongs to the Municipality of Trstenik and Rasina District, and has a total population of 2270 inhabitants. ${ }^{43}$ The first mention of Medveđa in existing written sources is in a list of caravanners from Levač in the nahiye of Petruš, dated in 1502. Seven people were listed in the village of Medveđa, and the same number in the village of Druga [Second] Medveđa, which is important for this paper. ${ }^{44}$ In an extensive census (tahrir defteri) of the Sanjak of Smederevo in 1530, two villages, Gornja (Upper) and Donja (Lower) Medveđa, are listed in the nahiye of Levač. ${ }^{45}$ Later on, two villages, Gornja and Donja Medveđa, are mentioned in a Turkish defter dated 1595/96. ${ }^{46}$ In the first Austrian census in 1718, only one village of Medveđa (Medovoda),

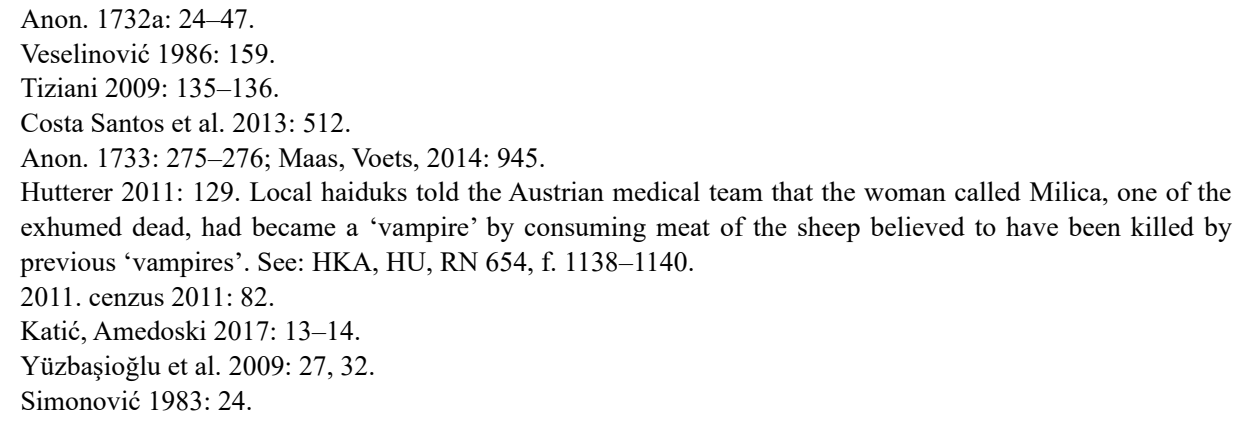


with six households, was recorded, and in documents from 1733-35 and 1737. ${ }^{47}$ Not many archaeological sites are listed in Medveđa. T. Bušetić mentioned one named Toponica on the border facing the villages of Milutovac and Velika Drenova, ${ }^{48}$ and there is one multilayered site called Šavran Mala on the banks of the West Morava. ${ }^{49}$ Toponica could be the location of the former village of Topoloniçe mentioned in the sixteenth century. ${ }^{50}$ However, north of present-day Medveđa, in the southeastern part of the neighboring village of Mijajlovac, there is an indicative toponym called Vampirlija.$^{51}$ This place does not appear on any topographical map, but oral tradition has preserved the name, which only appears in J. Mišković's Topographical Dictionary of the District of Jagodina, published in 1885. Vampirlija was described as a 'hill under the fertile ground on eastern side of the village of Mijajlovac'. ${ }^{52}$ The elevation of the hill approximately $297 \mathrm{~m}$ and is now covered with vineyards (Fig.2). ${ }^{53}$

So, what does this location have in common with the modern village of Medveđa more than $2 \mathrm{~km}$ to the south, other than a name that might be related to events in the distant past? We believe that the incident involving Arnold Paole could have taken place in Gornja Medveđa, a village that no longer exists, and that Vampirlija could have been a burial ground for that village. An alternative solution would be that two villages at some point merged ( since the last time two villages were mentioned was in $1595 / 96$, and by 1718 only one of them existed), so Vampirlija could have remained a graveyard for the northern part of a combined village. In the present-day cemetery of Medveđa, the oldest known gravestone dates from 1832. ${ }^{54}$ It is interesting to note that in the later Turkish defters (1739-1788), there are also two villages, but with an additional third-Srednja (Middle) Medveđa. ${ }^{55}$

Austrian maps would be of great help regarding this issue, especially from the earlier period of the Habsburg reign. Despite their deficiencies, the maps present the situation on the ground clearly. Having that in mind, it is confusing that Medveđa was drawn far north from the Morava river, on the right side of some smaller water source that is most likely the present day Mijajlovac Creek or the Bukovac Creek. On a map from 1737, this creek is named Medveđa Creek (Metvezka bach). The village was represented being farther north than the present day settlements along the Morava, such as Bogdanje, Velika Drenova, Kukljin, or the now defunct village of Ivanja. ${ }^{56}$ So, when drawn at that location it matches

$47 \quad$ Ibid. 26, 31.

48 Bušetić 1903: 477.

49 Rašković, Berić 2002: 141-142.

50 Yüzbaşioğlu et al. 2009: 55.

51 According to M. Pešikan, the suffix -lija represents a typical Turkish postposition -li, which serves as an answer to the question Nereli sin? [Where are you from?]. See: Pešikan 1958: 200; P. Radić points out that this suffix also has the function of 'creating ethnicity in a broader sense, from the name of a place or area, it builds derivatives in the meaning of inhabitants.' See: Radić 1999: 47. It has been noted that, in the Serbian literary language, this suffix appears exclusively in the class of beings, most often humans, with a basic meaning of bearers of a trait. See: Radić 2001: 39; S. Babić points out that a large number of derivatives of -lija belong to archaisms, provincialisms, folklorisms and historicisms, and that they are mostly stylistically marked ('insults'). See: Babić 1986: 187-188, 193. For more information on this suffix see: Klajn 2003: $145-146$.

52 Mišković 1885: 23.

53 Source: Google Earth.

54 I would like to thank Mr Ivan Nešić, a history professor from Medveđa for this information.

55 Pavlović 2016: 312, fig. 4.

56 This cannot be attributed to a cartographer's mistake, because on at least four Austrian maps the village of 
the location of Vampirlija Hill. Also on a fairly detailed map of military activity in the Kingdom of Serbia from 1738, Medveđa is again drawn further north, below a certain hill, and next to the source of a smaller watercourse.$^{57}$ On the Austrian maps drawn after this 'vampire' case (maps from 1737 and 1780s), Medveđa was drawn right on the banks of the West Morava River, at a location close to where it is now, ${ }^{58}$ suggesting that Gornja Medveđa could have been located at the source of this intermittent creek, under the right side of the Vampirlija Hill. However, there are currently no known archaeological traces of settlements on this area. Present day Rataj Mala, the separated, northern hamlet of Medveđa, is also located close to Vampirlija Hill, but on the southern side. ${ }^{59}$ On a map of the settlement of the Levač Nahiye from a period after the return of the Ottoman administration in the eighteenth century (1739-1788), Rataj is marked as a separate settlement in line with Srednja Medveđa, while Gornja Medveđa is drawn above them, exactly in the assumed area. ${ }^{60}$ Due to the absence of archaeological data, these considerations for new remain hypothetical.

According to the testimony of the owner of the property on the Vampirlija Hill, a lot of human bones were discovered during the plowing. Jawbones had been found in several locations and the witness claimed that the bones were mainly from younger individuals. No grave inventory was found. At least nine intact skeletons had been found and all bones were collected and reburied together into one single pit. The other villagers also confirmed that people had been buried there, but all of their stories were based on oral tradition. These testimonials should be taken with a grain of salt, but the information about the discovery of the bones along with a $30 \mathrm{~cm}$ long spear at this location lends them some credence. ${ }^{61}$

\section{Conclusion}

The purpose of this paper is to highlight and point to further archaeological research related to this topic. Local reports of human bones at this spot is a good starting point, but a lack of archaeological data hinders drawing more specific conclusions. Grave markers no longer exist, due to the material they were made from, such as wood, rotting away. A magnetic survey could be very informative, as would digging trial trenches to determine the existence of a necropolis at this location. In case of detecting $18^{\text {th }}$ century necropolis, anthropological and bioarchaeological examinations would be of highest importance. These analyses could provide an answer to the question of what kind of disease, which drew so much attention throughout Europe, was present in the Austrian Kingdom of Serbia. Also,

Medveđa was drawn north of the Morava River, in the interior. See: Weingartner 1738; Langer 1889: T. Ib; Simonović 1983: 61-62.

57 Weingartner 1738 .

58 Simonović 1983: 64-66.

59 On the left side of Rataj mala is located the toponym Staro brdo (The Old hill), for which some of the inhabitants consider to be the place of the 'Old Medveđa.' To our knowledge, no documented archaeological material was found there.

60 Pavlović 2016: 312, fig. 4.

${ }^{61}$ Rašković, Berić 2002: 145. The report states that the bones and the spear were found while digging for a vineyard in Rujišnik, which can be tentatively be related to this area, because large surfaces under vineyards between the villages of Mijajlovac and Rujišnik are positioned here. 
detecting and mapping surrounding sites that match chronologically could lead to a better understanding of the organization and function of the settlements along this border between two eighteenth century empires.

There is no evidence that incidents involving 'vampires' continued after January 1732. Assuming that similar things had continued to happen, ${ }^{62}$ a reasonable assumption would be that people left Gornja Medveđa and settled down by the river, which they considered to be safer. ${ }^{63}$ Vampirlija soon become only a toponym reflecting the memory of this interesting event in European history. To our knowledge, there is only one similar toponym that exists on the territory of Serbia under the name Vampirača, in the area of Smederevo. ${ }^{64}$ As time passed and due to various historical events, the memory of the 'vampire investigations' in Medveđa slowly faded away. When Joakim Vujić went to Medveđa in 1826, a century after the death of Arnold Paole, he made no mention of it. ${ }^{65}$ However, he did record another incident involving a 'vampire' in Novi Pazar that had occurred a few months before he arrived.$^{66}$ A likely assumption is that this was a result of population movements. Most people left their villages and towns throughout the eighteenth century and moved to the other side of the Sava and Danube Rivers. Some migrated in 1739 at the end of the Austrian occupation, but most left after Captain Koča's uprising in 1788, which broke out in this region of Serbia. ${ }^{67}$ Although some of them returned, they never settled at the exact location of their old homes. Taking this into consideration, it is not certain that the village's location is the same as it was in 1727, as Trbojević notes. ${ }^{68}$ Bušetić writes that the newcomers knew little about the older inhabitants or their traditions. When the new settlers arrived, the area was reclaimed by nature. The majority of the present day population of Medveđa came from the areas of Župa and Toplica after the First and the Second Serbian Uprisings. ${ }^{69}$ These circumstances created a break in historical memory because almost the entire local history from before new inhabitants arrived became part of tradition, as did the interpretation of certain toponyms. ${ }^{70}$

62 Based on the fact that in 1739 Arsenije IV Jovanović was forbidden by Austrian authorities from allowing immigrants to settle his country because of the 'pestilence,' it can be assumed that these and similar cases also appeared during the 1730 s.

63 An open question would be the emergence of the three Medveđa villages in the decades following. See: Pavlović 2016: 312, fig. 4. However, there is only one Medveđa village again on the map from 1783-1784, and from then on, there has been only one Medveđa. See: Pantelić 1936: T.III, 4; Simonović 1983: 39, 44, 46, 49.

64 Topografska karta 1:25000, Požarevac 3-3 (Osipaonica)

65 Vujić 1901: 143.

66 Ibid. 1902: 3-11.

Gavrilović 1986: 375-380.

Trbojević 2015: 101.

Bušetić 1903: 481, 485.

70 It seems that not the entire population migrated, because some groups must have stayed behind and conveyed the names of local streams, rivers, hills, mountains, etc. to the newcomers. However, the possibility exists that this toponym was a product of the newly arrived population. Yet, considering the rarity of toponyms of this root and its connection to the vicinity of the historically documented cases from Medveda, it would be reasonable to assume that the name of this toponym was inherited. This is supported by J. Vujić's writings from 1826 about the church ruins in Medveđa's neighboring village of Bogdanje. He says that this church was destroyed by the Turks 'in the time of the Prince Eugen's war' (1716-1718 A/N), which is probably oral tradition inherited and maintained by the local population at the time. See: Vujić 1901: 143. 
It was evident that, almost immediately after these investigations, all of Europe was introduced to this case by Dr. Glaser's father and even more so by some of the European newspapers, such as Mercure du France. This newspaper reproduced the Visum et Repertum in its entirety in the article 'Wampirs, fait singulier et des plus extraordinaires, s'il est vrai', published in May $1732 .{ }^{71}$ Many $\mathrm{PhD}$ dissertations written afterward include the events in Medveđa, such as Dissertationem de Hominibus Post Mortem Sanguisugis, Vulgo sic Dictis Vampyren, written by Johann Christoph Pohl in $1732,{ }^{72}$ Dissertatio de Vampyris Serviensibus by Johann Heinrich Zopf in 1733, ${ }^{73}$ and the work of M. Rantfs. ${ }^{74}$ Since then, the 'vampires' of Medveđa have been presented and described in almost every newspaper and magazine up until the present day. ${ }^{75}$ Petar Blagojević's case is the first documented Serbian 'vampire' case, but this second one created such a stir in Europe at the time that, for example, Visum et Repertum was presented to the Prussian King Friedrich Wilhelm I, ${ }^{76}$ and the future Pope Benedict XIV and Empress Maria Theresa took part in vampire debates. ${ }^{77}$

If a multidisciplinary, and primarily archeological approach, is taken to this issue, a well-documented historical event could be given material confirmation. From an academic perspective, this could lead to the further development of post-medieval archaeology in Serbia, especially of this short yet significant period of the Habsburg reign over the Kingdom of Serbia. Locally, expansion of this well-known story could have potential for tourism, which would probably very quickly gain a much wider audience.

\section{REFERENCES:}

Sources:

Anon. 'Beitrag zur Geschichte des Aberglaubens. Beschreibung des eigentlichen Verlaufs, welcher sich Ao. 1725 in dem Königreich Servien, und zwar den 6ten Apr. in dem Cracoiwazischen District mit den so genannten Wampyren zugetragen', Der neue Deutsche Zuschauer 7, Den 28. April, 1791, Zürich: Orell, Geßner, Füeßli, 1791, 326-329.

Frombald. 'Copia eines Schreibens aus dem Gradisker District', Wienerisches Diarium vom 21. Juli 1725 Kayserliche Hof-Buchdruckerey, Wien, 1725, 11-12.

Glaseri, J. F. 'Ex Litteris', Commercium Literarium ad Rei Medicae et Scientiae Naturalis Incermentum quo Ovicquid Novissime Observatum Agitatum Scriptum vel Peractum est

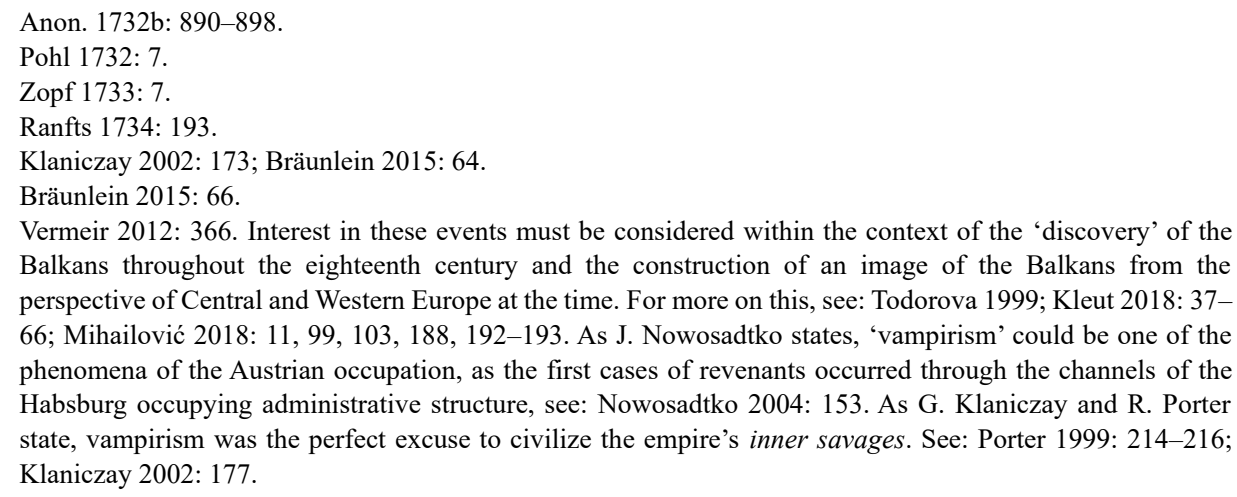
Balkans throughout the eighteenth century and the construction of an image of the Balkans from the perspective of Central and Western Europe at the time. For more on this, see: Todorova 1999; Kleut 2018: 37 66; Mihailović 2018: 11, 99, 103, 188, 192-193. As J. Nowosadtko states, 'vampirism' could be one of the phenomena of the Austrian occupation, as the first cases of revenants occurred through the channels of the Habsburg occupying administrative structure, see: Nowosadtko 2004: 153. As G. Klaniczay and R. Porter state, vampirism was the perfect excuse to civilize the empire's inner savages. See: Porter 1999: 214-216; Klaniczay 2002: 177. 
Succincte Dilucideque Exponitur. Annus MDCCXXXII, Norimbergae: Sumptibus Societatis, $1732,82-84$.

Grujić, R. 'Prilozi za istoriju Srbije u doba austrijske okupacije (1718-1739)', Spomenik SKA LII, Beograd: Srpska kraljevska akademija, 1914, 84-196. (Serbian Cyrillic)

Hofkammerarchiv, Wien, Hoffinanz Ungarn, Rote Nummer 654 (HKA, Wien)

fol. 1134-1136. Bericht des Cantagions-Medicus Glaser an die Jagodiner Kommandantur (nach dem 12.12.1731.).

fol. 1138-1140. Visum et Repertum Über die sogenannten Vampyrs oder Blutsauger so zu Medvegya in Servien an Türkhischen Gränz den 7 Januarii 1732 geschehen.

Mitrović, M. 'Podaci o Srbiji u protokolima Dvorskog ratnog saveta u Beču (1717-1740)', u: S. Gavrilović (ur.), Spomenik Odeljenja istorijskih nauka CXXX, Beograd: SANU, 1988, 7-384. (Serbian Cyrillic)

Novaković, S. (izd.) Zakonik Stefana Dušana cara srpskog 1349. i 1354, Beograd: Zadužbina Ilije M. Kolarca, 1898. (Serbian Cyrillic)

'Popis stanovništva, domaćinstava i stanova 2011. u Republici Srbiji', Uporedni pregled broja stanovnika 1948, 1953, 1961, 1971, 1981, 1991, 2002. i 2011. Podaci po naseljima, Beograd: Republički zavod za statistiku, 2011. (Serbian Cyrillic)

Rajković, Đ. (saopš.), 'Srpski narodni sabor meseca maja 1730. u Beogradu I. Beleške', Letopis Matice srpske 113, Novi Sad: Matica Srpska, 1872, 294-309. (Serbian Cyrillic)

Topografska karta 1:25000, Kruševac 3-1 (Medveđa), Beograd: Vojnogeografski institut.

Topografska karta 1:25000, Požarevac 3-3 (Osipaonica), Beograd: Vojnogeografski institut.

Vujić, J. Putešestvije po Serbiji, prva knjiga, Beograd: Srpska književna zadruga, 1901. (Serbian Cyrillic)

. Putešestvije po Serbiji, druga knjiga, Beograd: Srpska književna zadruga, 1902. (Serbian Cyrillic)

Weingartner, J. Theatre de la Guerre dans le Royaume de Servie en Originale, Vienne: Aug: Ferd: Heckenauer, 1738.

Yüzbaşioğlu et al. (eds.) MAD 506 Numarali Semendire Livâsi Icmâl Tahrir Defteri (937/1530) Dizin ve Tipkıbasım, Defter-i Hâkânî Dizisi: XIV, Ankara: T.C. Basbakanlik Devlet Arsivleri Genel Müdürlügü, 2009.

References:

András, K. 'A parasztság hétkoznapi élete a kőzépkori Magyarországon', A Veszprém megyei múzeumok közleményei 17, Veszprém, 1984, 221-231.

Anon. Acten-mäßige und Umständliche Relation von denen Vampiren oder Menschen-Saugern, welche sich in diesem und vorigen Jahren, im Königreich Servien, herfür gethan. Nebst einem Raisonnement darüber und einen Hand=Schreiben eines Officiers, des Prinz=Alexandrischen Regiments, aus Medvedia in Servie, Leipzig: Augusto Martini, 1732a.

Anon. 'Wampirs, fait singulier et des plus extraordinaires, s'il est vrai,' Mercure de France, May 1732, Paris, 1732b, 890-898.

Anon. 'Courtes reflexions physiques sur le vampirisme', Le Glaneur historique, moral, littéraire, galant et calottin III, A La Haye, 1733, 275-276.

Azinović Bebek, A. and Janeš, A. 'Groblje oko crkve sv. Nikole biskupa u Žumberku', u: S. Krznar et al. (ur.) Groblja i pogrebni običaji u srednjem i ranom novom vijeku na prostoru sjeverne Hrvatske. Zbornik radova prvog međunarodnog znanstvenog skupa srednjovjekovne arheologije Instituta za arheologiju. Zagreb, 4. lipnja 2014, Zagreb: Institut za arheologiju, 2016, 123-139.

Babić, S. Tvorba riječi u hrvatskom književnom jeziku, Nacrt za gramatiku. Zagreb, 1986. 
Barrowclough, D. The Malkin Tower, a Seventeenth-Century Witches Coven Discovered? The Archaeological and Historical Evidence Behind the British Witch Trails of 1612 Considered, Cambridge: Red Dagger Press, 2012, 1-21.

. Time to Slay Vampire Burials? The Archaeological and Historical Evidence for Vampires in Europe. First published: 19.10.2014, Cambridge: Red Dagger Press, 2014a, 1-10.

. 'The Wonderful Discovery of Witches' Unearthing the Occult: Necromancy and Magic in Seventeenth-Century England, Cambridge, 2014b, 1-12.

Barrowclough, D. and Hallam, J. 'The Devil's Footprints and Other Folklore: Local Legend and Archaeological Evidence in Lancashire', Folklore 119 (April 2008), London, 2008, 93-102.

Betsinger, T. K. and Scott, A. B. 'Govering from the Grave: Vampire Burials and Social Order in PostMedieval Poland', Cambridge Archaeological Journal 24 (3), Cambridge, 2014, 467-476.

Bräunlein, P. J. 'Furchterregende Randzonen der Aufklärung: Skandalon Vampirismus“, Zeitschrift für Anomalistik 15, Freiburg im Breisgau, 2015, 55-87.

Bušetić, T. 'Levač', u: J. Cvijić (ur.) Srpski etnografski zbornik, knjiga peta. Naselja srpskih zemalja II, Beograd: Srpska kraljevska akademija, 1903, 461-511. (Serbian Cyrillic)

Costa Santos, L. D. et al. 'Medical explanations for the myth of vampirism', Revista Medica de Minas Gerais 23(4), 2013, 510-514.

Čralić, L. Dugac, Ž. and Sardelić, S. 'Vampires in Dalmatia: The Example of Žrnovo on the Island of Korčula in the Eighteen Century', Review of Croatian History Vol. IX/1, Zagreb, 2014, 61-76.

Đorđević, M. 'Kraljevstvo Srbija 1720-1739', Doktorska disertacija, Niš: Filozofski fakultet, Univerzitet u Nišu, 2013. (Serbian Cyrillic)

Đorđević, M. and Miltojević, M. 'Prevencija habzburških vlasti od širenja zaraznih bolesti u Srbiji u prvoj polovini XVIII veka', Teme 4, Niš, 2014, 1611-1626. (Serbian Cyrillic)

Gavrilović, S. 'Ka srpskoj revoluciji', u: S. Gavrilović (ur.) Istorija srpskog naroda 4-1, Beograd: Srpska književna zadruga, 1986, 351-431. (Serbian Cyrillic)

Gavrilović, V. 'Podaci iz 1737. o narodnoj miliciji u Kraljevini Srbiji', Istorijski časopis XLVII, Beograd, 2000, 249-262. (Serbian Cyrillic)

Grenz, R. 'Archäologische Vampirbefunde aus dem westslawischen Siedlungsgebiet', Zeitschrift für Ostforschung 16, Marburg, 1967, 255-265.

Gusar, K. 'Jokina glavica - ranosrednjovjekovni grobovi', u: B. Marijanović (ur.) Tumuli iz Krneze i Podvršja kod Zadra (Tumuli from Krneza and Podvršje near Zadar), Zadar: Sveučilište u Zadru, 2012, 49-83.

Hanuliak, M. 'Vampirismus auf Gräberfeldern von der Wende des Früh- zum Hochmittelalter', Ethnographisch-Archäologische Zeitschrift 40, Leipzig, 1999, 577-585.

Hutterer, H. 'Vampire in Nordserbien', u: M. Follner and S. Seitschek (eds.) 300 Jahre Karl VI. (17111740). Spuren der Herrschaft des 'letzten' Habsburgers, hrsg. von der Generaldirektion des Österreichischen Staatsarchivs, Wien: Österreichisches Staatsarchiv, 2011, 126-135.

Katić, T. and Amedoski, D. 'Karavandžije nahije Petruš iz Levča 1502. godine', Mešovita građa XXXVIII, Beograd, 2017, 7-25. (Serbian Cyrillic)

Klajn, I. Tvorba reči u savremenom srpskom jeziku. Drugi deo - Sufiksacija i konverzija, Beograd, 2003. (Serbian Cyrillic)

Klaniczay, D. 'Decline of Witches and Rise of Vampires in $18^{\text {th }}$ Century Habsburg Monarchy', u: D. Oldridge (ed.) The Witchcraft Reader, London and New York: Routledge, 2002, 165-180.

Kleut, M. 'Komentari', u: P. V. Arbutina (ur.) Vampiri u Srbiji u XVIII veku. Knjiga i komentari, Beograd: Službeni glasnik, 2018, 37-73. (Serbian Cyrillic)

Koperkiewicz, A. 'Holy or Cursed? Some Reflections on Anomalies in Early Medieval Burials', Folia Archaeologica Balkanica III, Skopje, 2015, 491-505.

Korać, M. and Golubović, S. Viminacium - Više grobalja 2, Beograd: Arheološki institut, 2009. 
Krumphanzlová, Z. 'K otázce vampyrismu na slovanských pohřebišsích', Památky archeologické 52 (2), Praha, 1961, 544-549.

. 'Der Ritus der slawischen Skelettfriedhöfe der mittleren und jüngeren Burgwallzeit in Böhmen', Památky archeologické 57 (1), Praha, 1966, 277-327.

Krznar, S. and Bedić, Ž. 'Neuobičajeni ritus pokopavanja u srednjem i ranom novom vijeku na prostoru sjeverne Hrvatske', u: S. Krznar et al. (ur.) Groblja i pogrebni običaji u srednjem $i$ ranom novom vijeku na prostoru sjeverne Hrvatske. Zbornik radova prvog međunarodnog znanstvenog skupa srednjovjekovne arheologije Instituta za arheologiju. Zagreb, 4. lipnja 2014, Zagreb: Institut za arheologiju, 2016, 203-220.

Langer, J. 'Serbien unter der kaiserlichen Regierung 1717-1739', Mittheilungen des $k . k$. Kriegsarchivs, neue folge III, Wien, 1889, 155-247.

Leszek, G. and Kajkowski, K. 'Vampires, criminals or slaves? Reinterpreting "deviant burials' in early medieval Poland', World archaeology 45 (5), Abingdon-on-Thames, 2013, 780-796.

Maas, R. and Voets, P. 'The vampire in medical perspective: myth or malady?', QJM: An International Journal of Medicine 107(11), Oxford, 2014, 945-946.

Marjanović-Vujović, G. Trnjane, srpska nekropola (kraj XI - početak XIII veka), Beograd: Narodni muzej Beograd, 1984. (Serbian Cyrillic) . 'Burial Rite in the Necropolises of $11^{\text {th }}-12^{\text {th }}$ Century in the Territory of Serbia', Balcanoslavica 9, Prilep, 1986, 65-69.

Mezes, Á. Insecure Boundaries. Medical experts and the returning dead on the Southern Habsburg borderland. M.A. thesis, Budapest: Central European University, History Department, 2013.

. 'Georg Tallar and the 1753 Vampire Hunt: Administration, Medicine and the Returning Dead in the Habsburg Banat'. u: E. Pócz (ed.) The Magical and Sacred Medical World, Newcastle upon Tyne: Cambridge Scholars Publishing, 2019, 93-136.

Mihailović, V. Na granicama Balkana - L. F. Marsilji i rimska baština (1683-1701), Beograd: Balkanološki institut SANU, 2018. (Serbian Cyrillic)

Mikavica, D. et al. Srbi u Habzburškoj monarhiji od 1526. do 1918. 1 (Od Mohačke bitke do Blagoveštenskog sabora 1526-1862), Novi Sad: Prometej, 2016. (Serbian Cyrillic)

Mirković-Marić, N. 'Lokalitet Humka, srednjovekovna nekropola u selu Radljevo, na trasi PK Tamnava Zapadno polje', u: V. Filipović, R. Arsić and D. Antonović (ur.), Rezultati novih arheoloških istraživanja u severozapadnoj Srbiji i susednim teritorijama, Beograd-Valjevo: Srpsko arheološko društvo, Zavod za zaštitu spomenika kulture Valjevo, 2013, 249-257. (Serbian Cyrillic)

Mišković, J. ‘Topografski rečnik Jagodinskog okruga', Glasnik Srpskoga učenog društva 61, Beograd, 1885, 1-204. (Serbian Cyrillic)

Nowosadtko, J. 'Der 'Vampyris Serviensis" und sein Habitat: Impressionen von der österreichischen Militärgrenze', Militär und Gesellschaft in der Frühen Neuzeit 8(2), Potsdam, 2004, 151-167.

Pantelić, D. 'Vojno-geografski opisi Srbije pred Kočinu krajinu od 1783. i 1784. godine', Spomenik SKA LXXXII, Drugi razred 64, Beograd: Srpska kraljevska akademija, 1936. (Serbian Cyrillic)

Pavlović, M. Vojno administrativno uređenje Smederevskog sandžaka 1739-1788, Doktorska disertacija, Novi Sad: Univerzitet u Novom Sadu, Filozofski fakultet, Odsek za istoriju, 2016. (Serbian Cyrillic)

Pecinjački, S. 'Podaci o uređenju srbijanske milicije u 1728/29. godini', Zbornik radova Narodnog muzeja Čačak 7, Čačak, 1976, 149-186. (Serbian Cyrillic)

'Raspored domaće milicije austrijske Kraljevine Srbije u 1725. godini', Zbornik radova Narodnog muzeja Čačak 8, Čačak, 1977, 37-59. (Serbian Cyrillic)

Pešikan, M. 'O građenju imena stanovnika u odnosu na imena zemalja i mesta', Naš jezik - nova serija, knj. IX, sv. 3-4, Beograd, 1958, 196-205. (Serbian Cyrillic) 
Petković, S. and Ružić, M. 'Roman necropolis', u: S. Petković et al. (eds.), Roman and Medieval Necropolis in Ravna near Knjaževac, Belgrade: Archaeological institute, 2005, 23-176.

Pohl, J. C. Dissertationem De Hominibus Post Mortem Sanguisugis, Vulgo Sic Dictis Vampyren, Auctoritate Inclyti Philosophorum Ordinis, Publico Eruditorum Examini Die XXX. Aug. An. MDCCXXXII. Submittent M. Io. Christophorus Pohlius, Lignicens. Silesius Et Io. Gottlob Hertelius, Philos. Et Med. Stud, Lipsiae: Langenheim, 1732.

Popović, D. Srbija i Beograd od Požarevačkog do Beogradskog mira (1718-1739), Beograd: Srpska književna zadruga, 1950. (Serbian Cyrillic) . Velika seoba Srba, Beograd: Srpska književna zadruga, 1954. (Serbian Cyrillic)

Porter, R. 'Witchcraft and magic in Enlightenment, Romantic and Liberal thought', u: B. Ankarloo and S. Clark (eds.), Witchcraft and magic in Europe. The Eighteenth and Nineteenth centuries, London: The Athlone, 1999, 191-282.

Radić, P. 'Sufiks -lija u građenju imena stanovnika od imena mesta ili oblasti', Južnoslovenski filolog $L V$, Beograd, 1999, 47-66. (Serbian Cyrillic)

. Turski sufiksi u srpskom jeziku (sa osvrtom na stanje u makedonskom i bugarskom), Beograd: Institut za srpski jezik SANU, 2001. (Serbian Cyrillic)

Radosavljević, N. 'Valjevska episkopija u 'Izvešteniju' iz 1735. godine', Glasnik Istorijskog arhiva Valjevo 31, Valjevo, 1977, 37-44. (Serbian Cyrillic)

Ranfts, M. Tractat von dem Kauen und Schmatzen der Todten in Gräbern, worin die wahre Beschaffenheit derer Hungarischen Vampyrs und Blut-Sauger gezeigt, auch alle von dieser Materie bißher zum Vorschein gekommene Schrifften recensiret werden, Leipzig: Taubner, 1734.

Rangochev, K. and Hadzhiangelov, V. 'Gradăt. 'Nepravilnite mărtăvci' prez XII-XIX vek. (Po materiali ot grad Samokov i Samokovsko)', Elektronno spisanie 'Ongǎl". Meždunarodno referirano spisanie za etnologija, medievistika i arheologija. God. IV, 2012, br. 4, 2012, $163-$ 172. (Bulgarian Cyrillic)

Rašković, D. and Berić, N. 'Rezultati rekognosciranja antičkih i srednjovekovnih nalazišta trsteničke opštine i susednih oblasti', Glasnik Srpskog arheološkog društva 18, Beograd, 2002, 137-156. (Serbian Cyrillic)

Simonović, Đ. Levač - teritorija i naselja od kraja XII do početka XX veka, Rekovac-Beograd: Zavičajni klub Levčana, 1983. (Serbian Cyrillic)

Szabó, J. G. ‘Honfoglaláskori sirok Eger-Répástetőn', EMÉ 2, Eger, 1964, 105-139.

Tiziani, M. 'Vampires and vampirism: pathological roots of a myth', Antrocom 5/2, 2009, 133-137.

Todorova, M. Imaginarni Balkan, Beograd: Biblioteka XX vek, 1999.

Trbojević, D. 'Analiza pozitivnog i negativnog odnosa prema ekonomskom potencijalu geografske, istorijske i identitetske povezanosti sa motivom vampira u Srbiji', Antropologija 15, sv. 1, Beograd, 2015, 93-128. (Serbian Cyrillic)

Vermeir, K. 'Vampires as Creatures of the Imagination: Theories of Body, Soul, and Imagination in Early Modern Vampire Tracts (1659-1755)', u: Y. Haskell (ed.) Diseases of the Imagination and Imaginary Disease in the Early Modern Period, Turnhout: Brepols, 2012, 341-373.

Veselinović, R. 'Srbija pod austrijskom vlašću 1718-1739', u: S. Gavrilović (ur.), Istorija srpskog naroda 4-1, Beograd: Srpska književna zadruga, 1986, 106-162. (Serbian Cyrillic)

Warnke, D. 'Eine 'Vampir-Bestattung' aus dem frühgeschichtlichen Hügelgräberfeld in den 'Schwarzen Bergen' bei Ralswiek auf Rügen', Ausgrabungen und Funde 27, Berlin, 1982, 113-117.

Zopf, J. H. Dissertatio de Vampyris serviensibus quam supremi numinis auspicio praeside M. Ioanne Henr. Zopfio gymnasii assindiensis directore publice defendet respondens Christianus Fridericus Van Dalen Emmericensis in Acroaterio Maiori ad diem [] Martii 1733 horis antemeridianis, Duisburgi ad Rhenum: Johhanis Sas, Academiae Typographi, 1733. 


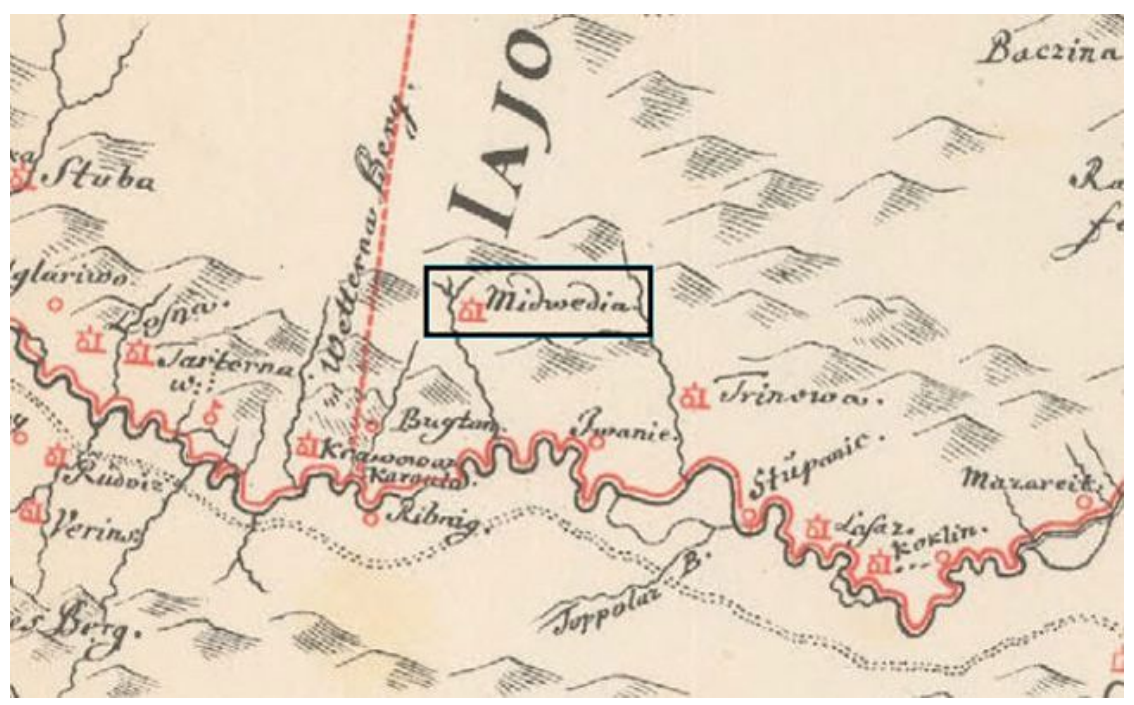

Figure 1 - Western Morava as the southern border of the Habsburg Kingdom of Serbia with the possition of the Medvedja village (Langer 1889, T.Ib; modified by A. Ristić)

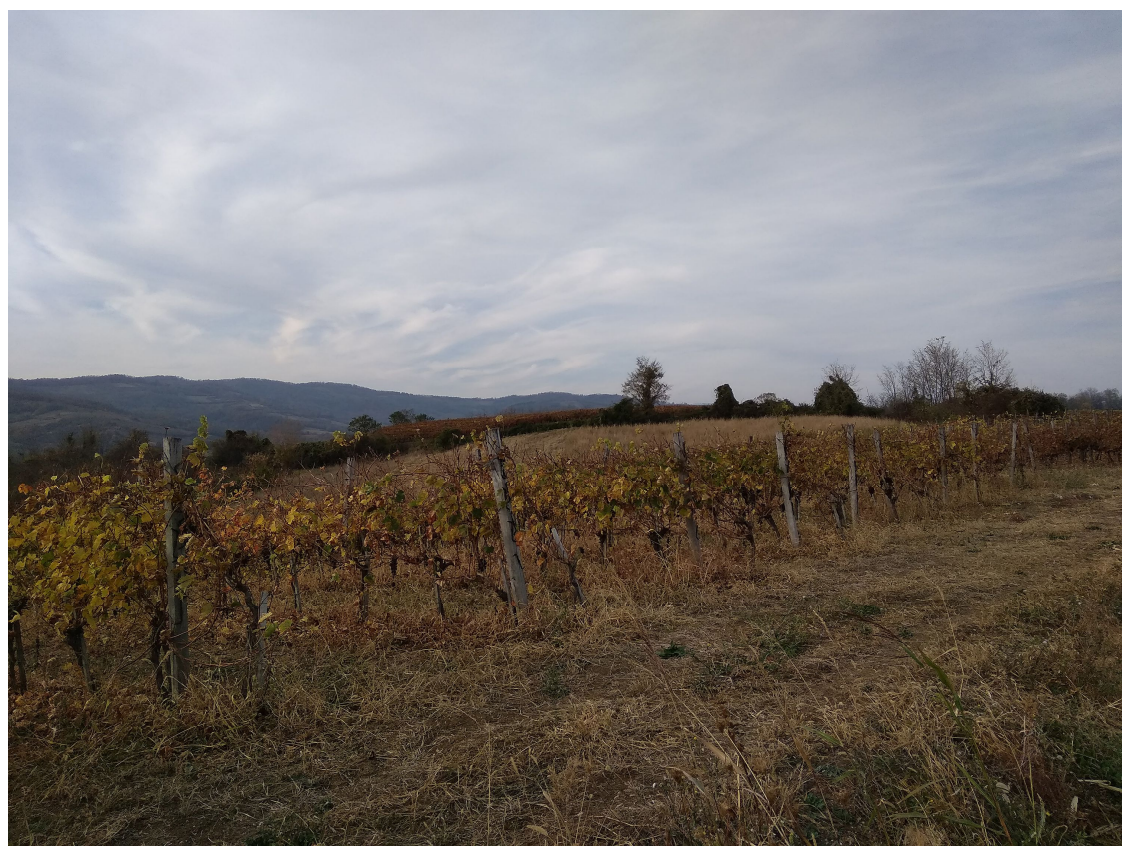

Figure 2 - The Vampirlija hill from the south (photo A. Ristić) 


\title{
АЛЕКСАНДАР РИСТИТ \\ Народна библиотека „Др Милован Спасић“ Рековац \\ БРДО ВАМПИРЛИЈА У СЕЛУ МИЈАЈЛОВЦУ (ТРСТЕНИК). Могућа локација рођења европске „вампирологије“
}

\begin{abstract}
Резиме
За разлику од Брам Стокеровог Дракуле, најпознатијег књижевног и филмског вампира који никада није заиста постојао, поједини „прави“ вампири су направили пометњу међу становништвом Србије XVIII века. У то време Србија је била под контролом државе Хабзбурга (1718-1739), па је ова појава на крају дошла до аустријских државних званичника. Ти догађаји су поткрепљени историјским медицинским документима и документима државноадминистративног типа, који ће убрзо потом проширити ове вести и изазвати велико интересовање широм Европе. Након првог случаја „вампиризма“ у подунавском селу Кисељева из 1725. године, други случај који се догодио у селу Медвеђа код данашњег Трстеника, на тадашњој јужној граници према Турској, много је снажније одјекнуо у тадашњој широј јавности. После доласка два лекарска тима у Медвеђу у децембру 1731. и јануару 1732. године, састављени су медицински извештаји у којима се недвосмислено наводи да су поједина ексхумирана тела била у „вампирском“ стању. Ти извештаји су касније долазили и до неких од највиших званичника Хабсбуршког царства, па чак и до царице Марије Терезије, пруског краља Фридриха Вилхелма I, као и папе Бенедикта XIV. Ми претпостављамо да се гробље тадашњег становништва, на коме су извршене ове ексхумације, могло налазити на узвишењу Вампирлија, северно од данашње Медвеђе, у атару суседног села Мијајловца. Ова хипотеза се може поткрепити чињеницом да су на овом узвишењу приликом пољопривредних радова ископаване људске кости, што се сазнаје на основу казивања власника имања. Историјски извори XVI века помињу села Горња и Доња Медвеђа, док се на аустријским картама насталим непосредно пре ових догађаја, село Медвеђа уцртава доста северније од појединих места која се и данас налазе на обали Западне Мораве, приближно на позицији која данас одговара поменутом узвишењу. Археолошка налазишта у близини овог узвишења нису лоцирана до данас. Геомагнетно снимање, а посебно пробно археолошко истраживање, могло би довести до потврде ове хипотезе, чиме би овај детаљан и исцрпан историјски извор добио и своју могућу материјалну потврду.
\end{abstract}

Кључне речи: Арнаут Павле, Медвеђа, Левач, Јагодински дистрикт, Краљевина Србија (1718-1739), Хабзбуршко царство, некропола, археологија XVIII века. 